\title{
Effects of baseline heart rate at sea level on cardiac responses to high-altitude exposure
}

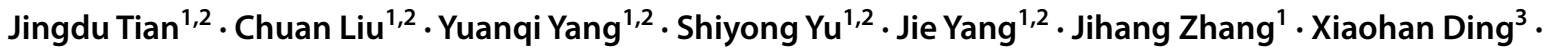 \\ Chen Zhang ${ }^{1,2} \cdot$ Rongsheng Rao $^{4} \cdot$ Xiaohui Zhao $^{1,2} \cdot$ Lan Huang $^{1,2} \mathbb{E}$
}

Received: 6 November 2019 / Accepted: 3 January 2020 / Published online: 17 January 2020

(c) The Author(s) 2020

\begin{abstract}
High-altitude (HA) exposure has been widely considered as a cardiac stress, and associated with altered cardiac function. However, the characteristics of cardiac responses to HA exposure are unclear. In total, 240 healthy men were enrolled and ascended to $4100 \mathrm{~m}$ by bus within 7 days. Standard echocardiography and color tissue Doppler imaging were performed at sea level and at $4100 \mathrm{~m}$. In all subjects, HA exposure increased HR [65 $(59,71)$ vs. $72(63,80)$ beats $/ \mathrm{min}, \mathrm{p}<0.001]$ but decreased the stroke volume index ( $\mathrm{SVi}$ ) [35.5 $(30.5,42.3)$ vs. $\left.32.9(27.4,39.5) \mathrm{ml} / \mathrm{m}^{2}, \mathrm{p}<0.001\right]$, leading to an unchanged cardiac index (CI). Moreover, baseline HR was negatively correlated with HA exposure-induced changes in HR $(r=-0.410$, $\mathrm{p}<0.001)$ and $\mathrm{CI}(\mathrm{r}=-0.314, \mathrm{p}<0.001)$. Following HA exposure, subjects with lowest tertile of baseline HR showed an increased HR $[56(53,58)$ vs. $65(58,73)$ beats/min, $p<0.001]$, left ventricular ejection fraction (LVEF) $[61.7(56.5,68.0)$ vs. $66.1(60.7,71.5) \%, p=0.004]$ and mitral $\mathrm{S}^{\prime}$ velocity [5.8 \pm 1.4 vs. $\left.6.5 \pm 1.9 \mathrm{~cm} / \mathrm{s}, \mathrm{p}=0.040\right]$. However, subjects with highest tertile of baseline HR showed an unchanged HR, LVEF and mitral S' velocity, but a decreased $\mathrm{E}^{\prime}$ velocity $[9.2 \pm 2.0$ vs. $8.4 \pm 1.8 \mathrm{~cm} / \mathrm{s}, \mathrm{p}=0.003$ ]. Our findings indicate that baseline HR at sea level could determine cardiac responses to HA exposure; these responses were characterized by enhanced LV function in subjects with a low baseline HR and by reduced LV myocardial velocity in early diastole in subjects with a high baseline HR.
\end{abstract}

Keywords High altitude $\cdot$ Cardiac function $\cdot$ Heart rate $\cdot$ Echocardiography

Jingdu Tian, Chuan Liu and Yuanqi Yang have contributed equally to this work

Electronic supplementary material The online version of this article (https://doi.org/10.1007/s10554-020-01769-w) contains supplementary material, which is available to authorized users.

Xiaohui Zhao

doctorzhaoxiaohui@yahoo.com

$\triangle$ Lan Huang

huanglan260@126.com

1 Institute of Cardiovascular Diseases of PLA, the Second Affiliated Hospital, Third Military Medical University (Army Medical University), Chongqing 400037, China

2 Department of Cardiology, the Second Affiliated Hospital, Third Military Medical University (Army Medical University), 183 Xinqiao street, Shapingba district, Chongqing 400037, China

3 Department of Geriatric Cardiology, Chinese PLA General Hospital, Beijing 100038, China

4 Department of Medical Ultrasonics, the Second Affiliated Hospital, Third Military Medical University (Army Medical University), Chongqing 400037, China

\section{Introduction}

High-altitude (HA) exposure has been widely considered as a cardiac stress during short-term or prolonged periods at HA for the purposes of recreation, sports, work or military training. Well-adapted cardiac performance may facilitate oxygen delivery to tissues when no oxygen therapy is available. It has been well documented that the global systolic left ventricular (LV) and right ventricular (RV) functions are well preserved, but both ventricles show altered filling patterns, subendocardial systolic dysfunction, and the increase in mean pulmonary arterial pressure (mPAP) [1-3]. Notably, there may be a potential association between altered cardiac functions and the incidence of acute mountain sickness [4], whereas the increase in mPAP may limit exercise capacity at HA [5, 6]. Although the cardiac responses to HA exposure are of great significance, the detailed characterizations are largely unknown.

The initial cardiac responses to acute HA exposure include the increase in heart rate (HR) and cardiac output 
(CO) but with no change in stroke volume (SV). However, after a few days of acclimatization (3-5 days), the $\mathrm{CO}$ begins to decrease and returns to baseline level with a higher HR and a lower SV [7]. The increase in HR is mainly due to sympathetic activation [8], whereas the decrease in SV is attributed to a decrease in blood volume, an increase in mPAP, the impairment of myocardial relaxation and an increase in HR, all of which contribute to the altered filling patterns of both ventricles [9]. During these physiological processes, the change in HR seems to be a critical determinant of cardiac performance at HA. In addition, evidence has shown that the resting HR is a predictor of LV dysfunction and heart failure, and a high HR may contribute to the development of regional and global LV dysfunction [10]. Furthermore, HR may directly impact cardiac function, and a low HR might be more beneficial for patients with systolic heart failure than an intermediate HR [11]. However, whether the baseline HR of lowlanders exhibits diverse cardiac responses during HA travels is still unclear.

Considering that tissue Doppler imaging (TDI) allows for the noninvasive determination of myocardial velocity in a shape-independent manner and may provide an exact evaluation for cardiac function [12], we conducted the present study to investigate the cardiac responses under acute HA exposure and the impact of baseline HR by using standard Doppler echocardiography as well as color TDI.

\section{Methods}

\section{Study design and participants}

A total of 240 healthy men who were born or permanently live at sea level (SL, $<500 \mathrm{~m}$, above sea level, asl) were recruited in Chongqing, China, and ascended to HA in succession from Yanggongqiao (Chongqing, China, $400 \mathrm{~m}$, asl) to Litang (Sichuan, China, $4100 \mathrm{~m}$, asl) by bus with a stair-like journey within 7 days and finally arrived on July 9, 10, 11 and 12, 2013, respectively. Data collections were performed at SL and within $5 \pm 2 \mathrm{~h}$ after arriving at $4100 \mathrm{~m}$. Exclusion criteria were known malignant tumors, cardiovascular diseases, any chronic cardiovascular therapy, pulmonary diseases, liver and kidney dysfunction, hematologic diseases, history of HA exposure in the recent 6 months, history of angioedema, and psychiatric disorders. This study was registered under the Chinese Clinical Trial Registration (No: ChiCTR-RCS-12002232, https://www.chictr.org.cn). All procedures and protocols were approved by the Clinical Research Ethics Board at the Army Medical University (Third Military Medical University) (NO: 2012014) and conformed to the standards set by the Declaration of Helsinki. All subjects volunteered to participate in this study and gave written informed consent.

\section{Clinical examinations}

Age, height, body weight and smoking history were recorded. Body mass index (BMI) was calculated as weight $(\mathrm{kg}) /[\text { height }(\mathrm{m})]^{2}$, body surface area (BSA) was calculated as $0.0061 \times$ height $(\mathrm{cm})+0.0128 \times$ weight $(\mathrm{kg})$ $-0.1529)$. Resting HR was from electrocardiogram. Systolic blood pressure (SBP) and diastolic blood pressure (DBP) were measured with an Omron HEM-6200 (Japan) with the subject resting in a sitting position for at least $5 \mathrm{~min}$. The oxygen saturation $\left(\mathrm{SaO}_{2}\right)$ values were obtained from warmed hands from the fingertips with a pulse oximeter (Nonin ONYX OR9500, USA) after at least $10 \mathrm{~min}$ of rest.

\section{Echocardiographic image acquisition}

Two-dimensional, Doppler and tissue Doppler echocardiography were performed by registered sonographers by using CX50 ultrasound systems (Philips Ultrasound System, Andover, MA, USA) as previously described [13]. All images were obtained at end-expiration with the subjects in the left lateral decubitus position after at least 10 min of rest to allow the subjects to reach steady state. Two-dimensional grayscale harmonic images with 70-90 frames per second and color tissue Doppler images with 110-140 frames per second were saved digitally for subsequent offline analysis (QLAB 10.5; Philips Healthcare, Andover, MA, USA).

\section{Two-dimensional and Doppler echocardiography}

The measurements were conducted according to the current guideline [14]. The LV end-diastolic and end-systolic volumes (EDV and ESV, respectively), stroke volume (SV, $=\mathrm{EDV}-\mathrm{ESV})$, cardiac output $(\mathrm{CO},=\mathrm{SV} \times \mathrm{HR})$ and $\mathrm{LV}$ ejection fraction $[\mathrm{LVEF},=(\mathrm{EDV}-\mathrm{ESV}) / \mathrm{EDV} \times 100]$ were measured or calculated as previous described (Yang et al. 2015). The early (E), late (A) diastolic wave peak velocities and $\mathrm{E} / \mathrm{A}$ were measured from mitral or tricuspid pulse-Doppler inflow. According to current guideline [15], the end-systolic and end-diastolic RV areas (ESA and EDA) were obtained on an apical RV focused view, and the fractional area change (FAC) was calculated as follows: $(\mathrm{EDA}-\mathrm{ESA}) / \mathrm{EDA} \times 100$. Pulsed-wave Doppler imaging of the pulmonary artery was performed and the pulmonary acceleration time (AT) and ejection time (ET) were measured, and the mean pulmonary artery pressure (mPAP) was estimated as follows: when the AT was longer than $120 \mathrm{~ms}, \mathrm{mPAP}=79-(0.45 \times \mathrm{AT})$, and when the AT 
was shorter than $120 \mathrm{~ms}, \mathrm{mPAP}=90-(0.62 \times \mathrm{AT})$ [6]. The maximal velocity of the tricuspid regurgitation jet (TRV) was measured, and the systolic pulmonary arterial pressure (SPAP) was calculated with the Bernoulli equation $(\mathrm{TRV}$ in $\mathrm{m} / \mathrm{s})$ : $\mathrm{SPAP}=4 \times \mathrm{TRV}^{2}+10$.

\section{Color tissue Doppler imaging}

Tissue velocities were measured from the apical 4-chamber view in a standard manner through color TDI analysis in 147 randomly selected subjects as a subgroup. The systolic $\left(\mathrm{S}^{\prime}\right)$ positive wave and early diastolic $\left(\mathrm{E}^{\prime}\right)$ tissue velocities were measured at the center of the lateral walls from the mitral or tricuspid annulus from the average of three cardiac cycles (Fig. 2). The E/e' ratio was calculated to evaluate the LV and RV filling pressures [16]. The myocardial performance index (MPI) was also measured using the TDI method, which allowed a global estimation of both LV and RV systolic and diastolic function [15].

\section{Reproducibility}

Observer reliability of main echocardiographic measurements was assessed in 20 randomly selected subjects. Interobserver variability was performed by two separate observers, and intraobserver variability was performed by the same observer at least 1 month apart. Both the intraobserver and interobserver variabilities were tested using the intraclass correlation coefficient (ICC) by Cronbach's $\alpha$.

\section{Statistical analysis}

Statistical analyses were performed using SPSS 22.0 for Windows (IBM Corp., Armonk, NY, USA). Continuous variables were presented as either the mean \pm standard deviation (SD) or median (25th, 75th percentile) according to their normality results from the Kolmogorov-Smirnov test. The differences between parameters at sea level and at HA were compared with paired t-tests or Wilcoxon rank-sum tests. Correlations were performed using linear regression. Trend tests were used for cross-group comparisons of continuous variables. Categorical variables were expressed as counts and percentages and analyzed using the $\chi^{2}$ test. Statistical power calculations were evaluated (PASS software, version 11, NCSS, LLC, Kaysville, UT, USA), and more than $80 \%$ statistical power was achieved for detect significant differences between subgroups using a two-sided alpha of 0.05. All statistical tests were twosided, and a p-value $<0.05$ was statistically significant and was presented in bold in Tables.

\section{Results}

\section{The general cardiac responses following HA exposure}

The basic information of the participants, including age, height, weight, BSA, BMI, ethnicity, and smoking history is shown in Supplemental Table S1. As shown in Table 1, following HA exposure, the HR $[65(59,71)$ vs. $72(63,80)$ beats/min, $\mathrm{p}<0.001$ ], SBP and DBP were significantly increased, whereas the $\mathrm{SaO}_{2}$ level was decreased compared with the values at SL. The EDVi, and ESVi and the calculated SVi $\left[35.5(30.5,42.3)\right.$ vs. $32.9(27.4,39.5) \mathrm{ml} / \mathrm{m}^{2}$, $\mathrm{p}<0.001]$ were significantly reduced. Consequently, CI was unaltered. However, the LVEF was improved [(62.1 $(56.5,67.8)$ vs. $65.2(58.8,70.4) \%, p=0.001]$. Moreover, there were significant reductions in the mitral peak E-wave velocity, peak A-wave velocity and the E/A ratio. Furthermore, the mitral $\mathrm{E}^{\prime}$ was significantly reduced $(9.0 \pm 2.2 \mathrm{vs}$. $8.2 \pm 1.9 \mathrm{~cm} / \mathrm{s}, \mathrm{p}<0.001)$ but the mitral $\mathrm{S}^{\prime}$ was comparable before and after HA exposure. Therefore, the LV MPI was significantly increased but the LV filling index (mitral E/E ratio was calculated to evaluate ratio) was also decreased after HA exposure.

Following HA exposure, the decrease in RV EDAi and the unchanged RV ESAi resulted in a significant reduction in RV FAC $[45.5(42.3,48.0)$ vs. $41.8(38.0,44.8) \%$, $\mathrm{p}<0.001]$. Furthermore, there were significant reductions in tricuspid peak E-wave velocity, peak A-wave velocity and the $\mathrm{E} / \mathrm{A}$ ratio, although the tricuspid $\mathrm{S}^{\prime}$ and tricuspid $\mathrm{E}^{\prime}$ remained unchanged. Consequently, the tricuspid $\mathrm{E} / \mathrm{E}^{\prime}$ ratio was decreased. Nevertheless, the RV MPI and mPAP were significantly increased, and the percentage of subjects with functional TR increased from $56.3 \%$ to $80.0 \%$. The calculated SPAP from TRV was also increased (Table 1).

\section{Associations of baseline HR and the changes in HR and $\mathrm{Cl}$ values following $\mathrm{HA}$ exposure}

Results from the linear regression analysis identified that the $\Delta \mathrm{HR}$ after HA exposure were negatively associated with the baseline HR ( $r=-0.410, p<0.001)$ (Fig. 1a). Moreover, the $\Delta \mathrm{CI}$ was also negatively associated with the baseline HR $(\mathrm{r}=-0.314, \mathrm{p}<0.001)$ (Fig. 1b).

\section{LV functional responses to HA exposure in subjects with different tertiles of baseline HR}

The subjects in our study were divided into three groups based on the tertiles of their baseline HR at SL: lowest tertile HR (LT), middle tertile HR (MT) and highest tertile HR 
Table 1 The physiologic parameters and echocardiographic parameters of participants at sea level and at high altitude

\begin{tabular}{|c|c|c|c|c|}
\hline Variables & Sea-level & High-altitude & $\Delta$ value & $\mathrm{P}$ value \\
\hline \multicolumn{5}{|c|}{ Physiologic parameters $(\mathrm{n}=240)$} \\
\hline HR (beats/min) & $65(59,71)$ & $72(63,80)$ & $6.4 \pm 11.4$ & $<0.001$ \\
\hline $\mathrm{SaO}_{2}(\%)$ & $98(97,98)$ & $89(88,91)$ & $-8.0(-10.0,-7.0)$ & $<0.001$ \\
\hline $\mathrm{SBP}(\mathrm{mmHg})$ & $112(106,119)$ & $120(113,127)$ & $8.0(1.0,16.0)$ & $<0.001$ \\
\hline $\mathrm{DBP}(\mathrm{mmHg})$ & $67.6 \pm 8.6$ & $78.9 \pm 9.2$ & $11.3 \pm 11.0$ & $<0.001$ \\
\hline \multicolumn{5}{|c|}{ 2D and Doppler echocardiography $(n=240)$} \\
\hline LV EDVi $\left(\mathrm{ml} / \mathrm{m}^{2}\right)$ & $58.2(50.2,66.6)$ & $51.7(43.6,59.0)$ & $-6.8(-16.6,3.0)$ & $<0.001$ \\
\hline LV ESVi (ml/m²) & $22.5 \pm 7.9$ & $18.4 \pm 5.8$ & $-4.0 \pm 7.7$ & $<0.001$ \\
\hline $\mathrm{SVi}\left(\mathrm{ml} / \mathrm{m}^{2}\right)$ & $35.5(30.5,42.3)$ & $32.9(27.4,39.5)$ & $-2.7(-9.6,3.8)$ & $<0.001$ \\
\hline $\mathrm{CI}\left(\mathrm{L} / \mathrm{min} / \mathrm{m}^{2}\right)$ & $2.2(1.9,2.7)$ & $2.3(1.8,2.8)$ & $0.05(-0.53,0.56)$ & 0.652 \\
\hline LVEF (\%) & $62.1(56.5,67.8)$ & $65.2(58.8,70.4)$ & $2.5(-5.0,9.0)$ & 0.001 \\
\hline Mitral E (cm/s) & $98.1(88.6,107.2)$ & $78.7(68.0,91.8)$ & $-17.1 \pm 18.0$ & $<0.001$ \\
\hline Mitral A (cm/s) & $51.7 \pm 11.7$ & $49.6 \pm 10.8$ & $-1.1 \pm 15.0$ & $\mathbf{0 . 0 3 4}$ \\
\hline Mitral E/A ratio & $1.90(1.57,2.27)$ & $1.61(1.36,1.92)$ & $-0.26(-0.63,0.07)$ & $<0.001$ \\
\hline $\mathrm{RV}$ EDAi $\left(\mathrm{cm}^{2} / \mathrm{m}^{2}\right)$ & $13.4(12.1,15.0)$ & $12.3(11.1,14.2)$ & $-1.2 \pm 2.8$ & $<0.001$ \\
\hline RV ESAi $\left(\mathrm{cm}^{2} / \mathrm{m}^{2}\right)$ & $7.5(6.6,8.2)$ & $7.1(6.3,8.4)$ & $-0.2 \pm 1.7$ & 0.183 \\
\hline RV FAC (\%) & $45.5(42.3,48.0)$ & $41.8(38.0,44.8)$ & $-3.5 \pm 5.4$ & $<0.001$ \\
\hline Tricuspid E (cm/s) & $74.1 \pm 13.0$ & $61.9 \pm 12.7$ & $-12.2 \pm 15.0$ & $<0.001$ \\
\hline Tricuspid A (cm/s) & $36.0(30.6,42.2)$ & $33.1(28.4,40.0)$ & $-4.1(-10.5,3.6)$ & $<0.001$ \\
\hline Tricuspid E/A ratio & $2.00(1.67,2.38)$ & $1.80(1.46,2.25)$ & $-0.18 \pm 0.68$ & $<0.001$ \\
\hline \multicolumn{5}{|c|}{ Color tissue doppler imaging $(n=147)$} \\
\hline Mitral $\mathrm{S}^{\prime}(\mathrm{cm} / \mathrm{s})$ & $6.3 \pm 1.6$ & $6.2 \pm 1.6$ & $-0.1 \pm 2.2$ & 0.416 \\
\hline Mitral E' (cm/s) & $9.0 \pm 2.2$ & $8.2 \pm 1.9$ & $-0.8 \pm 2.5$ & $<0.001$ \\
\hline Mitral E/E' ratio & $10.6(9.3,12.7)$ & $9.2(7.8,11.9)$ & $-1.2(-3.6,1.2)$ & $<0.001$ \\
\hline LV MPI & $0.41 \pm 0.13$ & $0.48 \pm 0.15$ & $0.06 \pm 0.19$ & $<0.001$ \\
\hline Tricuspid $\mathrm{S}^{\prime}(\mathrm{cm} / \mathrm{s})$ & $7.7 \pm 1.5$ & $7.6 \pm 1.3$ & $-0.2 \pm 1.7$ & 0.255 \\
\hline Tricuspid E' (cm/s) & $7.2(5.7,8.6)$ & $7.5(6.0,8.9)$ & $0.3(-1.2,1.9)$ & 0.186 \\
\hline Tricuspid $\mathrm{E} / \mathrm{E}^{\prime}$ ratio & $10.4(8.5,13.0)$ & $8.5(6.7,10.4)$ & $-1.8(-4.6,0.2)$ & $<0.001$ \\
\hline RV MPI & $0.52(0.38,0.67)$ & $0.63(0.48,0.75)$ & $0.09 \pm 0.28$ & $<0.001$ \\
\hline \multicolumn{5}{|c|}{ Pulmonary haemodynamics $(\mathrm{n}=240)$} \\
\hline $\mathrm{AT} / \mathrm{ET}$ & $0.37(0.34,0.40)$ & $0.31(0.21,0.35)$ & $-0.06 \pm 0.07$ & $<0.001$ \\
\hline mPAP $(\mathrm{mmHg})$ & $18.6(15.4,22.3)$ & $24.3(20.2,32.6)$ & $7.7(1.1,15.6)$ & $<0.001$ \\
\hline $\operatorname{TR}[\mathrm{n}(\%)]$ & $135(56.3)$ & $192(80.0)$ & & $<0.001$ \\
\hline TRV (m/s) & $2.15(1.91,2.33)$ & $2.46(2.26,2.78)$ & & $<0.001$ \\
\hline SPAP $(\mathrm{mmHg})$ & $28.5(24.7,31.8)$ & $34.1(30.4,41.0)$ & & $<0.001$ \\
\hline
\end{tabular}

Values are median (25th to 75 th quartile) or mean \pm SD

$A$ mitral or tricuspid inflow late diastolic velocity; $A T$ pulmonary acceleration time; $C I$ cardiac index; $D B P$ diastolic blood pressure; $E$ mitral or tricuspid inflow early diastolic velocity; $E T$ pulmonary ejection time; $E^{\prime}$ peak early diastolic velocity with tissue Doppler imaging at the mitral or tricuspid annular; FAC right ventricular fractional area of change; $H R$ heart rate; $L V$ left ventricular; $L V E D V i$ left ventricular enddiastolic volume index; $L V E S V i$ left ventricular end-systolic volume index; $L V E F$ left ventricle ejection fraction; $M P I$ myocardial performance index; $R V$ right ventricular; $R V E D A i$ right ventricular end-diastolic area index; $R V E S A i$ right ventricular end-systolic area index; $S^{\prime}$ peak systolic velocity with tissue Doppler imaging at the mitral or tricuspid annular; $E^{\prime}$ early diastolic velocity at the mitral or tricuspid annular; $\mathrm{SaO}_{2}$ Oxygen saturation; SBP systolic blood pressure; SPAP systolic pulmonary artery pressure; $S V i$ stroke volume index; $T R$ tricuspid regurgitation; $T R V$ tricuspid regurgitation velocity
(HT), and their baseline characteristics were summarized in Supplemental Table S1, which showed no significant differences. However, following HA exposure, the HR was significantly increased in the LT $[56(53,58)$ vs. $65(58,73)$ beats/ min, $\mathrm{p}<0.001]$ and MT groups but not in the HT group; the $\Delta \mathrm{HR}$ was higher in the LT group than in the MT group (Fig. 1c, e), although the changes in SBP, DBP and $\mathrm{SaO}_{2}$ value were equally among the groups (Table 2 ).

After HA exposure, the EDVi and ESVi uniformly decreased in all three groups; no significant differences were 

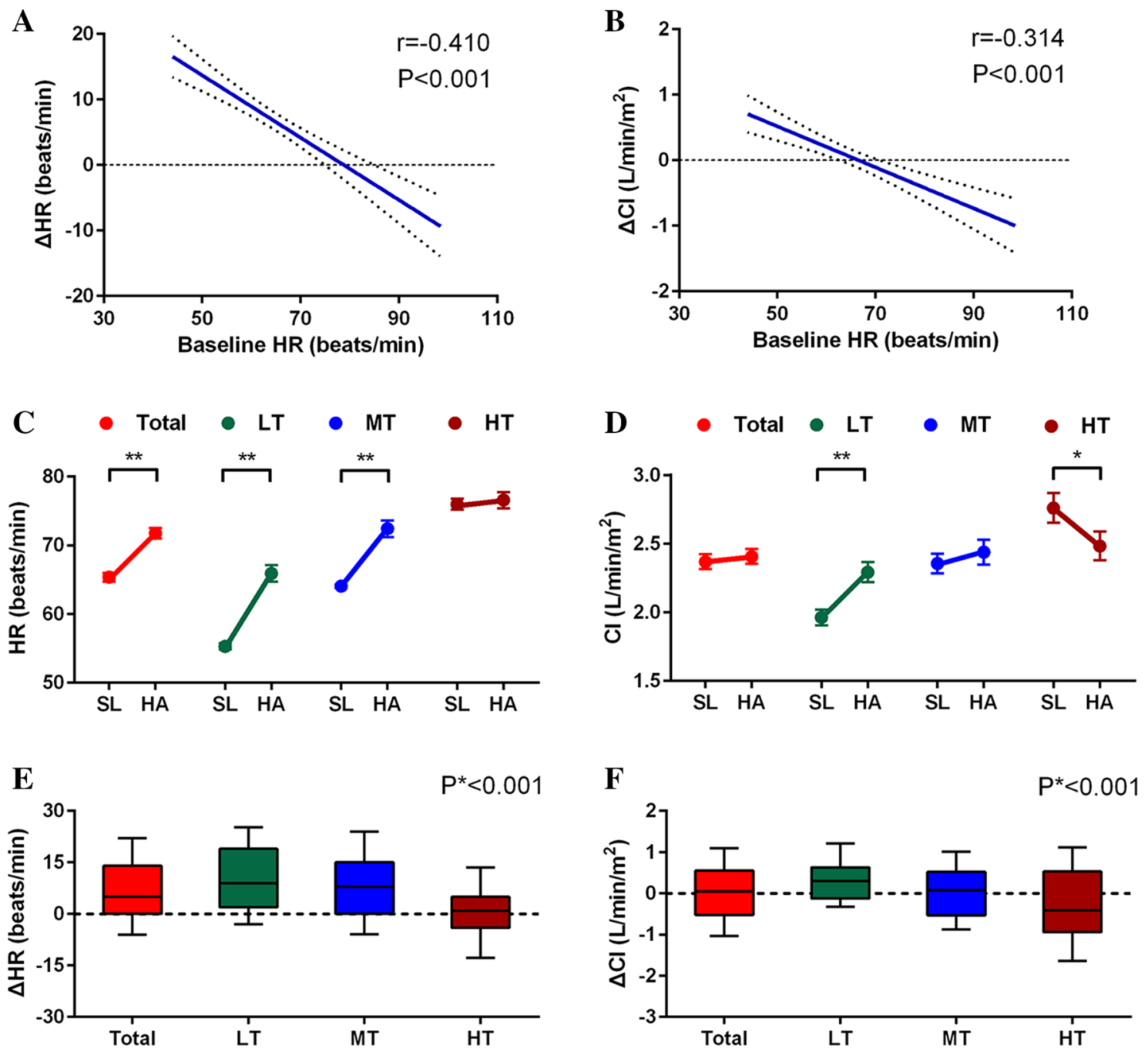

Fig. 1 Correlations of baseline HR with the changes in HR and CI in response to HA exposure. The change in the values ( $\Delta$ values) of HR (a) and CI (b) were negatively correlated with the baseline HR after HA exposure. The effects of HA exposure on HR (c), the CI (d), and

their $\Delta$ values (e, f) in total subjects and different tertiles of baseline HR. $S L$ sea level, $H A$ high altitude, $H R$ heart rate, $C I$ cardiac index, $L T$ lowest tertile HR, $M T$ middle tertile HR, $H T$ highest tertile HR, $* \mathrm{p}<0.05, * * \mathrm{p}<0.01, \mathrm{p} * \mathrm{p}$ value for trend

found in $\triangle E D V i$ and $\triangle E S V i$, although the EDVi and ESVi for subjects at SL gradually decreased with increasing baseline HR. However, the calculated SVi, which was decreased in total subjects, was unchanged in the LT group but decreased in the MT and HT groups, and the CI increased in the LT group but decreased in the HT group (Fig. 1d, f). Moreover, the LVEF only significantly increased in the LT group [61.7 $(56.5,68.0)$ vs. $66.1(60.7,71.5) \%, p=0.004]$ but not in the MT and HT groups. Although the mitral E/A ratios of subjects at SL gradually decreased with increasing baseline $\mathrm{HR}$, the mitral peak E-wave and the E/A ratio uniformly decreased in all three groups after HA exposure (Fig. 3a). Interestingly, the mitral $\mathrm{S}^{\prime}$ significantly increased in the LT group $(5.8 \pm 1.4$ vs. $6.5 \pm 1.9 \mathrm{~cm} / \mathrm{s}, \mathrm{p}=0.040)$ (Fig. 2a, b), whereas the mitral $\mathrm{E}^{\prime}$ was decreased in the MT $(8.9 \pm 2.0$ vs. $8.0 \pm 2.0 \mathrm{~cm} / \mathrm{s}, \mathrm{p}=0.008)$ and $\mathrm{HT}(9.2 \pm 2.0$ vs. $8.4 \pm 1.8 \mathrm{~cm} / \mathrm{s}, \mathrm{p}=0.003$ ) groups (Fig. $2 \mathrm{c}, \mathrm{d}$ ); the mitral $\mathrm{E} / \mathrm{E}^{\prime}$ ratio and LV MPI were decreased in the MT and HT groups but not in the LT group following HA exposure (Table 2).

\section{RV functional responses to HA exposure in subjects with different tertiles of baseline HR}

As shown in Table 3, after HA exposure, the RV EDAi and the calculated RV FAC uniformly decreased in all three groups. Similarly, subjects in all the three groups showed uniform reductions in E-wave velocity, $\mathrm{E} / \mathrm{A}$, and $\mathrm{E} / \mathrm{E}^{\prime}$ and increases in the mPAP, TR, TRV and SPAP, although the mitral and tricuspid E/A ratio of subjects at SL gradually decreased with increasing baseline HR (Fig. 3). Moreover, 
Table 2 Physiologic parameters and Left ventricular parameters of participants in different baseline resting heart rate at sea level and at high altitude

\begin{tabular}{|c|c|c|c|c|c|c|c|c|c|}
\hline \multirow[t]{2}{*}{ Variables } & \multicolumn{2}{|l|}{ Lowest tertile } & \multirow[t]{2}{*}{$P$ value } & \multicolumn{2}{|l|}{ Middle Tertile } & \multirow[t]{2}{*}{$P$ value } & \multicolumn{2}{|l|}{ Highest tertile } & \multirow[t]{2}{*}{$P$ value } \\
\hline & Sea level & High altitude & & Sea level & High altitude & & Sea level & High altitude & \\
\hline \multicolumn{10}{|c|}{ Physiologic parameters $(\mathrm{n}=77 / 80 / 83)$} \\
\hline $\begin{array}{l}\text { HR (beats/ } \\
\text { min) }\end{array}$ & $56(53,58)$ & $65(58,73)$ & $<0.001$ & $64(62,66)$ & $72(64,78)$ & $<0.001$ & $75(70,79)$ & $77(69,84)$ & 0.280 \\
\hline $\mathrm{SaO}_{2}(\%)$ & $98(97,98)$ & $89(88,91)$ & $<0.001$ & $98(97,98)$ & $89(88,91)$ & $<0.001$ & $98(97,98)$ & $89(88,91)$ & $<0.001$ \\
\hline $\begin{array}{l}\text { SBP } \\
\quad(\mathrm{mmHg})\end{array}$ & $112(107,119)$ & $\begin{array}{l}120 \\
\quad(112,127)\end{array}$ & $<0.001$ & $110(104,118)$ & $\begin{array}{l}118 \\
(112,126)\end{array}$ & $<0.001$ & $115(108,120)$ & $\begin{array}{l}123 \\
(115,127)\end{array}$ & $<0.001$ \\
\hline $\begin{array}{l}\mathrm{DBP} \\
\quad(\mathrm{mmHg})\end{array}$ & $67.0 \pm 8.5$ & $78.9 \pm 8.8$ & $<0.001$ & $67.3 \pm 9.0$ & $77.4 \pm 8.9$ & $<0.001$ & $68.4 \pm 8.2$ & $80.5 \pm 9.6$ & $<0.001$ \\
\hline \multicolumn{10}{|c|}{ 2D and Doppler echocardiography $(n=77 / 80 / 83)$} \\
\hline $\begin{array}{r}\text { LV EDVi } \\
\left(\mathrm{ml} / \mathrm{m}^{2}\right)\end{array}$ & $\begin{array}{l}57.1(50.2, \\
66.3)\end{array}$ & $\begin{array}{l}54.2(44.8, \\
58.9)\end{array}$ & 0.004 & $\begin{array}{l}58.1(51.1, \\
65.8)\end{array}$ & $\begin{array}{l}52.2(45.4, \\
59.6)\end{array}$ & $<0.001$ & $\begin{array}{l}58.7(49.2 \\
67.8)\end{array}$ & $\begin{array}{l}49.1(41.5, \\
58.9)\end{array}$ & $<0.001$ \\
\hline $\begin{array}{r}\text { LV ESVi } \\
\left(\mathrm{ml} / \mathrm{m}^{2}\right)\end{array}$ & $22.2 \pm 7.6$ & $18.4 \pm 5.8$ & $<0.001$ & $22.5 \pm 7.1$ & $18.9 \pm 5.9$ & $<0.001$ & $22.6 \pm 8.8$ & $18.0 \pm 5.7$ & $<0.001$ \\
\hline $\mathrm{SVI}\left(\mathrm{ml} / \mathrm{m}^{2}\right)$ & $\begin{array}{l}35.9(30.6 \\
41.2)\end{array}$ & $\begin{array}{l}33.5(29.1, \\
39.9)\end{array}$ & 0.268 & $\begin{array}{l}35.8(30.8, \\
41.5)\end{array}$ & $\begin{array}{l}33.2 \\
\quad(28.1,39.8)\end{array}$ & 0.012 & $\begin{array}{l}33.6(30.0, \\
44.1)\end{array}$ & $\begin{array}{l}30.6(23.8, \\
39.0)\end{array}$ & $\mathbf{0 . 0 0 4}$ \\
\hline $\begin{array}{l}\mathrm{CI}(\mathrm{L} / \mathrm{min} / \\
\left.\mathrm{m}^{2}\right)\end{array}$ & $1.9(1.6,2.3)$ & $2.2(1.8,2.6)$ & $<0.001$ & $2.3(2.0,2.6)$ & $2.3(1.9,2.8)$ & 0.568 & $2.5(2.1,3.4)$ & $2.3(1.8,3.1)$ & 0.012 \\
\hline $\operatorname{LVEF}(\%)$ & $\begin{array}{l}61.7(56.5, \\
68.0)\end{array}$ & $\begin{array}{l}66.1(60.7, \\
71.5)\end{array}$ & 0.004 & $\begin{array}{l}61.6(56.1, \\
67.5)\end{array}$ & $\begin{array}{l}64.6(58.5 \\
71.5)\end{array}$ & 0.128 & $\begin{array}{l}63.1(55.7, \\
69.1)\end{array}$ & $\begin{array}{c}64.9(57.5 \\
69.3)\end{array}$ & 0.112 \\
\hline $\begin{array}{l}\text { Mitral E } \\
(\mathrm{cm} / \mathrm{s})\end{array}$ & $\begin{array}{c}99.9(90.5 \\
111.8)\end{array}$ & $\begin{array}{l}75.2(68.0, \\
90.0)\end{array}$ & $<0.001$ & $\begin{array}{c}96.6(88.4 \\
105.4)\end{array}$ & $\begin{array}{c}79.5(68.9 \\
91.6)\end{array}$ & $<0.001$ & $\begin{array}{c}99.9(90.5 \\
111.8)\end{array}$ & $\begin{array}{l}75.2(68.0 \\
90.0)\end{array}$ & $<0.001$ \\
\hline $\begin{array}{c}\text { Mitral A } \\
(\mathrm{cm} / \mathrm{s})\end{array}$ & $48.0 \pm 11.2$ & $46.2 \pm 10.1$ & 0.324 & $50.4 \pm 11.1$ & $51.2 \pm 11.9$ & 0.662 & $56.4 \pm 11.3$ & $51.3 \pm 9.8$ & $<0.001$ \\
\hline $\begin{array}{l}\text { Mitral E/A } \\
\text { ratio }\end{array}$ & $\begin{array}{l}2.16(1.71, \\
2.50)\end{array}$ & $\begin{array}{l}1.71(1.47, \\
2.15)\end{array}$ & $<0.001$ & $\begin{array}{l}1.89(1.65 \\
2.27)\end{array}$ & $\begin{array}{l}1.61 \\
\quad(1.31,1.86)\end{array}$ & $<0.001$ & $\begin{array}{l}1.78(1.45 \\
2.07)\end{array}$ & $\begin{array}{l}1.53 \\
\quad(1.33,1.81)\end{array}$ & $<0.001$ \\
\hline \multicolumn{10}{|c|}{ Color tissue doppler imaging $(n=43 / 47 / 57)$} \\
\hline $\begin{array}{r}\text { Mitral S' } \\
(\mathrm{cm} / \mathrm{s})\end{array}$ & $5.8 \pm 1.4$ & $6.5 \pm 1.9$ & $\mathbf{0 . 0 4 0}$ & $5.8 \pm 1.6$ & $6.5 \pm 1.5$ & $\mathbf{0 . 0 3 5}$ & $6.7 \pm 1.8$ & $6.3 \pm 1.5$ & 0.167 \\
\hline $\begin{array}{l}\text { Mitral E' } \\
(\mathrm{cm} / \mathrm{s})\end{array}$ & $8.7 \pm 2.6$ & $8.2 \pm 1.9$ & 0.262 & $8.9 \pm 2.0$ & $8.0 \pm 2.0$ & 0.008 & $9.2 \pm 2.0$ & $8.4 \pm 1.8$ & 0.003 \\
\hline $\begin{array}{l}\text { Mitral E/E' } \\
\text { ratio }\end{array}$ & $\begin{array}{c}10.6(8.6 \\
13.6)\end{array}$ & $8.6(7.6,12.4)$ & 0.058 & $\begin{array}{c}10.7(9.4 \\
12.6)\end{array}$ & $9.5(8.6,11.6)$ & 0.014 & $10.3(9.2,12.0)$ & $8.7(7.3,11.2)$ & 0.011 \\
\hline LV MPI & $0.42 \pm 0.16$ & $0.48 \pm 0.17$ & 0.097 & $0.44 \pm 0.12$ & $0.51 \pm 0.16$ & 0.014 & $0.38 \pm 0.12$ & $0.45 \pm 0.14$ & 0.001 \\
\hline
\end{tabular}

Values are median (25th to 75 th quartile) or mean \pm SD

Abbreviations as in Table 1

no significant differences were found in the tricuspid $\mathrm{S}^{\prime}$ and $\mathrm{E}^{\prime}$ among the three groups. However, increases in the RV MPI were found in the LT and HT groups but not in the MT group.

\section{Inter- and intra-observer variability}

The intraclass correlation coefficients for absolute agreement (ICCa) of the main cardiac structural and functional parameters for the intra- and inter-observer measurements are shown in Supplemental Table S2. All the measurements showed excellent or good agreements.

\section{Discussion}

In this study, we demonstrated that the baseline HR of subjects at SL was associated with the changes in HR and CI after HA exposure. The HR increased in the LT and MT groups but not in the HT group, and the SVi decreased in the MT and HT groups but not in the LT group; this resulted in an increase in $\mathrm{CI}$ in the LT group, an unchanged $\mathrm{CI}$ in the MT group and a decreased CI in the HT group. Furthermore, after acute HA exposure, the global LV systolic function and myocardial contractility were enhanced, and the LV myocardial velocity in early diastole was 
Fig. 2 Color tissue Doppler imaging and the curves. The systolic $\left(\mathrm{S}^{\prime}\right)$ positive wave and early diastolic $\left(\mathrm{E}^{\prime}\right)$ tissue velocities were measured at the center of the lateral walls from the mitral annulus in subjects with lowest tertile baseline HR at sea level (a) and high altitude (b), with highest tertile baseline $\mathrm{HR}$ at sea level (c) and high altitude (d)
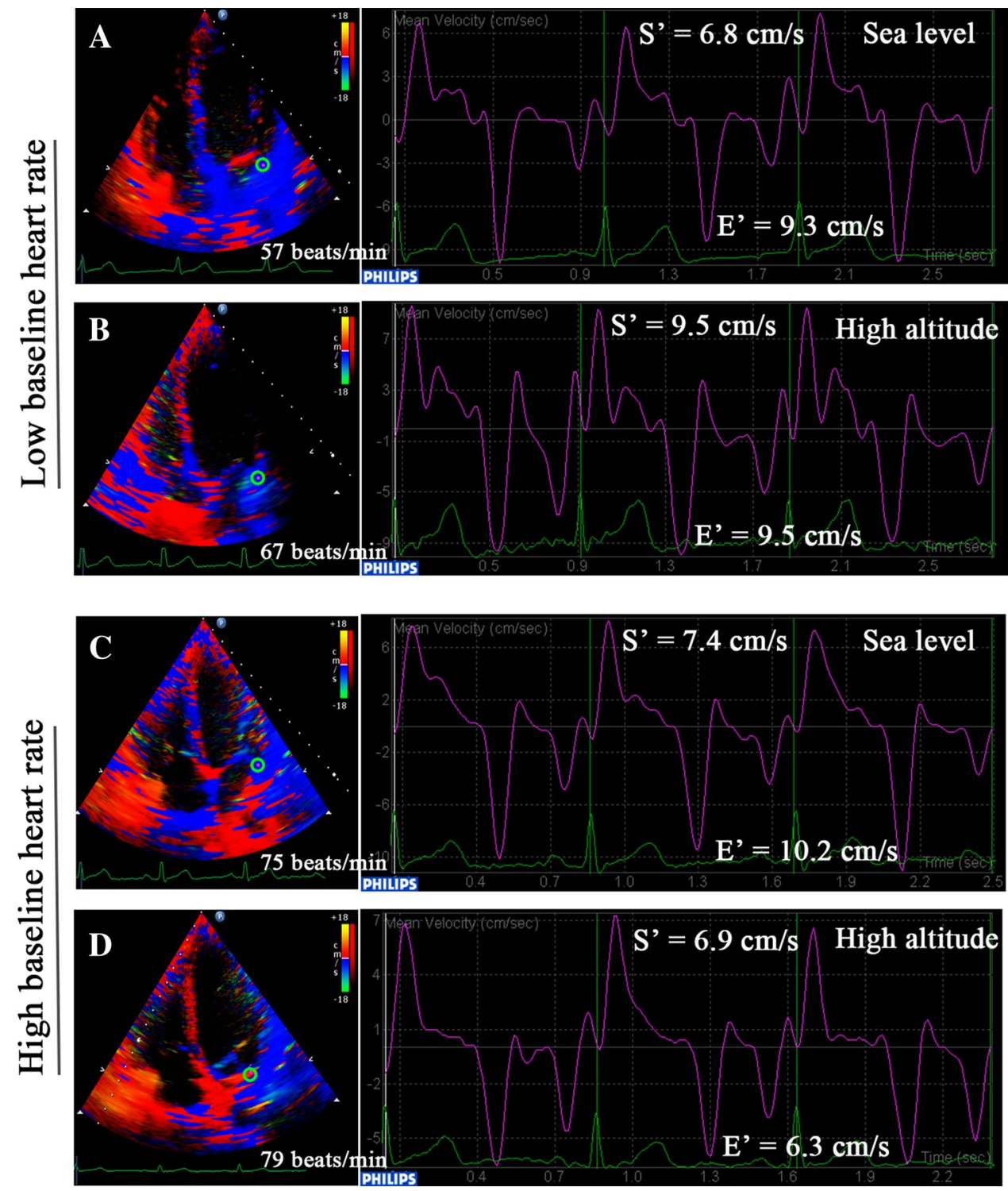

unchanged for subjects in the LT group; however, while the global LV systolic function and myocardial contractility were unaltered, there was a decline in LV myocardial velocity in early diastole for subjects in the HT group. Our findings indicated that the baseline HR of subjects at sea level could determine the cardiac responses to acute HA exposure, which are characterized by enhanced LV function in subjects with a low baseline HR and by reduced LV myocardial velocity in early diastole in subjects with a high baseline HR (Fig. 4).

The reasons for the decline in SVi have been continuously debated for over 40 years, but the exact mechanisms involved are still not completely understood. Undoubtedly, HR, preload, afterload and ventricular function are the main determinants of SV [9]. In this study, we found that an increase in HR was accompanied by reductions in the mitral and tricuspid E/A inflow ratios and E/e' ratio, whereas a high HR at HA could shorten the diastolic period, which then reduces LV filling [17]. Moreover, we also found that the mPAP was greatly elevated and the RV function decreased. During acute HA exposure, the high mPAP was mainly attributed to HPV, which in turn increased the RV afterload, impaired RV function and led to ventricular mismatch. Subsequently, these alterations decreased the volume of blood returning to the left ventricle, thus lowering the SV [18]. In our study, the abovementioned factors that potentially affect SV might be compensated by an enhanced LV systolic function, which results from the unchanged SVi in subjects with a low baseline HR. Additionally, in our present study, the decrease in SVi following acute HA exposure for subjects with a high baseline HR might be attributed to a combination of the abovementioned factors with the unaltered LV systolic function as well as impaired LV myocardial relaxation; this parameter has been suggested to be an 
Table 3 Right ventricular parameters of participants in different baseline resting heart rate at sea level and at high altitude

\begin{tabular}{|c|c|c|c|c|c|c|c|c|c|}
\hline \multirow[t]{2}{*}{ Variables } & \multicolumn{2}{|l|}{ Lowest tertile } & \multirow[t]{2}{*}{$P$ value } & \multicolumn{2}{|l|}{ Middle tertile } & \multirow[t]{2}{*}{$P$ value } & \multicolumn{2}{|l|}{ Highest tertile } & \multirow[t]{2}{*}{$P$ value } \\
\hline & Low-altitude & High-altitude & & Low-altitude & High-altitude & & Low-altitude & High-altitude & \\
\hline \multicolumn{10}{|c|}{ 2D and Doppler echocardiography $(n=77 / 80 / 83)$} \\
\hline $\begin{array}{l}\text { RV EDAi } \\
\left(\mathrm{cm}^{2} / \mathrm{m}^{2}\right)\end{array}$ & $\begin{array}{l}13.6(12.2, \\
15.0)\end{array}$ & $\begin{array}{l}12.2(11.1 \\
14.0)\end{array}$ & $<0.001$ & $\begin{array}{c}14.1(12.7, \\
15.3)\end{array}$ & $\begin{array}{l}13.1(11.2, \\
15.1)\end{array}$ & 0.007 & $\begin{array}{l}12.8(11.2 \\
14.9)\end{array}$ & $\begin{array}{c}12.0(10.9, \\
13.7)\end{array}$ & 0.016 \\
\hline $\begin{array}{l}\text { RV ESAi } \\
\left(\mathrm{cm}^{2} / \mathrm{m}^{2}\right)\end{array}$ & $7.7(6.9,8.3)$ & $7.0(6.6,8.4)$ & $\mathbf{0 . 0 3 6}$ & $7.4(6.7,8.6)$ & $7.9(6.4,8.8)$ & 0.988 & $7.2(6.0,8.1)$ & $7.0(5.8,8.0)$ & 0.602 \\
\hline RV FAC (\%) & $\begin{array}{l}44.0(42.1 \\
48.2)\end{array}$ & $\begin{array}{l}42.0(38.6, \\
44.0)\end{array}$ & $<0.001$ & $\begin{array}{l}45.9(42.7, \\
48.8)\end{array}$ & $\begin{array}{c}40.6(37.5, \\
44.2)\end{array}$ & $<0.001$ & $\begin{array}{c}45.5(41.9 \\
47.8)\end{array}$ & $\begin{array}{l}42.0(39.1, \\
45.5)\end{array}$ & $<0.001$ \\
\hline $\begin{array}{l}\text { Tricuspid E } \\
(\mathrm{cm} / \mathrm{s})\end{array}$ & $75.4 \pm 11.1$ & $62.4 \pm 13.4$ & $<0.001$ & $73.4 \pm 12.0$ & $61.5 \pm 12.0$ & $<0.001$ & $73.6 \pm 15.2$ & $61.8 \pm 12.9$ & $<0.001$ \\
\hline $\begin{array}{l}\text { Tricuspid A } \\
(\mathrm{cm} / \mathrm{s})\end{array}$ & $\begin{array}{l}34.3 \\
\quad(29.3,41.3)\end{array}$ & $\begin{array}{l}31.0 \\
\quad(24.9,39.0)\end{array}$ & 0.100 & $\begin{array}{l}35.5 \\
\quad(29.7,39.5)\end{array}$ & $\begin{array}{l}31.1 \\
\quad(27.7,37.3)\end{array}$ & 0.018 & $\begin{array}{l}38.5 \\
\quad(33.1,48.3)\end{array}$ & $\begin{array}{l}35.7 \\
\quad(31.4,41.7)\end{array}$ & 0.006 \\
\hline $\begin{array}{l}\text { Tricuspid } \\
\text { E/A ratio }\end{array}$ & $\begin{array}{l}2.18(1.84, \\
2.53)\end{array}$ & $\begin{array}{l}2.00(1.52, \\
2.42)\end{array}$ & 0.038 & $\begin{array}{l}2.07(1.67 \\
2.52)\end{array}$ & $\begin{array}{l}1.84(1.54 \\
2.28)\end{array}$ & 0.016 & $\begin{array}{l}1.86(1.51 \\
2.21)\end{array}$ & $\begin{array}{l}1.62(1.40, \\
2.02)\end{array}$ & $\mathbf{0 . 0 3 2}$ \\
\hline \multicolumn{10}{|c|}{ Color tissue doppler imaging $(n=43 / 47 / 57)$} \\
\hline $\begin{array}{l}\text { Tricuspid } \mathrm{S}^{\prime} \\
(\mathrm{cm} / \mathrm{s})\end{array}$ & $7.9 \pm 1.2$ & $7.7 \pm 1.4$ & 0.515 & $7.7 \pm 1.7$ & $7.7 \pm 1.2$ & 0.990 & $7.6 \pm 1.6$ & $7.3 \pm 1.4$ & 0.169 \\
\hline $\begin{array}{l}\text { Tricuspid } E^{\prime} \\
(\mathrm{cm} / \mathrm{s})\end{array}$ & $7.1(5.7,8.4)$ & $7.6(5.8,9.1)$ & 0.284 & $7.1(5.4,8.7)$ & $7.8(6.5,9.0)$ & 0.105 & $7.3(5.2,8.4)$ & $7.2(5.6,8.8)$ & 0.646 \\
\hline $\begin{array}{l}\text { Tricuspid } \\
\text { E/E' ratio }\end{array}$ & $\begin{array}{c}10.6(8.4 \\
12.8)\end{array}$ & $8.1(6.3,10.4)$ & 0.009 & $\begin{array}{c}10.4(8.7 \\
14.2)\end{array}$ & $7.8(6.7,9.8)$ & $<0.001$ & $\begin{array}{c}10.1(8.5 \\
12.9)\end{array}$ & $8.8(7.4,12.0)$ & $\mathbf{0 . 0 3 4}$ \\
\hline RV MPI & $\begin{array}{l}0.53(0.40 \\
0.67)\end{array}$ & $\begin{array}{l}0.63(0.52 \\
0.81)\end{array}$ & 0.004 & $\begin{array}{l}0.58(0.47 \\
0.74)\end{array}$ & $\begin{array}{c}0.64(0.48, \\
0.75)\end{array}$ & 0.342 & $\begin{array}{l}0.49(0.33 \\
0.63)\end{array}$ & $\begin{array}{c}0.63(0.45 \\
0.75)\end{array}$ & 0.004 \\
\hline \multicolumn{10}{|c|}{ Pulmonary haemodynamics $(\mathrm{n}=77 / 80 / 83)$} \\
\hline AT/ET & $\begin{array}{c}0.38(0.34 \\
0.40)\end{array}$ & $\begin{array}{l}0.31(0.28 \\
0.35)\end{array}$ & $<0.001$ & $\begin{array}{l}0.37(0.34 \\
0.41)\end{array}$ & $\begin{array}{l}0.31(0.26 \\
0.35)\end{array}$ & $<0.001$ & $\begin{array}{l}0.37(0.35 \\
0.40)\end{array}$ & $\begin{array}{c}0.32(0.27 \\
0.35)\end{array}$ & $<0.001$ \\
\hline $\mathrm{mPAP}, \mathrm{mmHg}$ & $\begin{array}{l}16.9(12.4, \\
21.3)\end{array}$ & $\begin{array}{l}24.3(20.1, \\
29.9)\end{array}$ & $<0.001$ & $\begin{array}{l}18.6(15.6, \\
22.1)\end{array}$ & $\begin{array}{l}23.1 \\
\quad(20.0,33.5)\end{array}$ & $<0.001$ & $\begin{array}{c}19.7(16.9 \\
22.7)\end{array}$ & $\begin{array}{l}24.2 \\
\quad(20.4,33.8)\end{array}$ & $<0.001$ \\
\hline $\operatorname{TR}[\mathrm{n}(\%)]$ & $38(49.4)$ & $61(79.2)$ & $<0.001$ & $48(60.0)$ & $68(85.0)$ & $<0.001$ & $49(59.0)$ & $63(75.9)$ & $\mathbf{0 . 0 2 0}$ \\
\hline TRV (m/s) & $\begin{array}{l}2.15(2.05, \\
2.33)\end{array}$ & $\begin{array}{l}2.54(2.26 \\
2.83)\end{array}$ & $<0.001$ & $\begin{array}{l}2.10(1.92, \\
2.35)\end{array}$ & $\begin{array}{l}2.45(2.24, \\
2.73)\end{array}$ & $<0.001$ & $\begin{array}{l}2.15(1.87 \\
2.33)\end{array}$ & $\begin{array}{l}2.43(2.30, \\
2.73)\end{array}$ & $<0.001$ \\
\hline SPAP $(\mathrm{mmHg})$ & $\begin{array}{l}28.5 \\
\quad(26.9,31.8)\end{array}$ & $\begin{array}{l}35.7(30.4, \\
42.1)\end{array}$ & $<0.001$ & $\begin{array}{l}27.7 \\
\quad(24.7,32.1)\end{array}$ & $\begin{array}{l}34.0 \\
\quad(30.1,39.8)\end{array}$ & $<0.001$ & $\begin{array}{l}28.4 \\
\quad(24.0,31.6)\end{array}$ & $\begin{array}{l}33.7 \\
\quad(31.1,39.9)\end{array}$ & $<0.001$ \\
\hline
\end{tabular}

Values are median (25th to 75 th quartile) or mean \pm SD

Abbreviations as in Table 1

important factor for the decrease in SV and was associated with the decrease in cardiac high-energy phosphate metabolism under acute HA hypoxia [19].

Due to the shortening of the diastolic period, subjects with a high baseline HR showed lower ventricular filling at sea level than at HA, as described in the present study and by previous data [20]. However, following acute HA exposure, the changes in ventricular filling seemed to be equal across subjects with different levels of baseline HR. On the other hand, the increases in the afterload of both ventricles, which could also contribute to the decline in $\mathrm{SV}$, were also uniform across subjects with different levels of baseline HRs. These uniform changes suggest that there must be other reasons that account for the diverse changes in SV for subjects with different levels of baseline HRs after acute HA exposure. The increase in HR was more pronounced in subjects with a low baseline HR than in those with a high baseline HR, which might be attributed to the progressive decrease in maximal heart rate or heart rate reserve with increasing hypoxia [21]; however, the LV myocardial systolic velocity $\left(\mathrm{S}^{\prime}\right)$ also increased in these low baseline HR subjects following acute HA exposure, which led to an increased LVEF, and consequently, the SVi was maintained. Moreover, the resting heart rate was positively correlated with $\mathrm{LV} \mathrm{S}^{\prime}$ as well as $\mathrm{E}^{\prime}$, independent of sex and age [22]. In our study, although the LV E' at HA was unchanged in subjects in the LT group, subjects in the MT and HT group showed a significant decrease in LV E', which suggested that a high baseline HR was associated with impaired LV myocardial relaxation, restoring forces, or increased lengthening load under acute HA exposure and might additionally contribute 

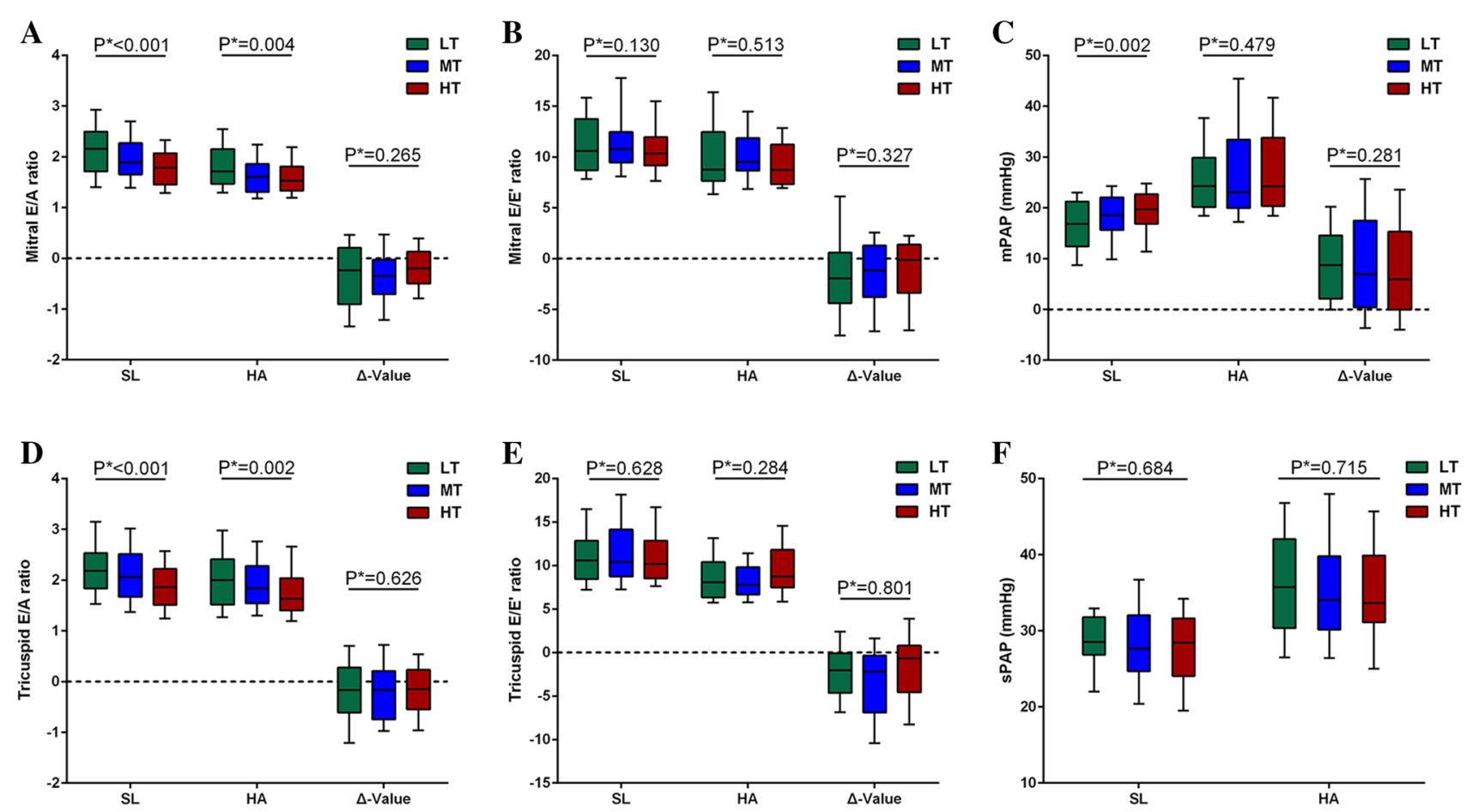

Fig. 3 The effects of different baseline HRs on ventricular fillings and $\mathrm{RV}$ afterload in subjects at SL or HA. a Mitral E/A ratio, b mitral $\mathrm{E} / \mathrm{e}^{\prime}$ ratio, c mean pulmonary artery pressure (mPAP), d tricuspid
E/A ratio, e tricuspid E/e' ratio, $\mathbf{f}$ systolic pulmonary artery pressure (SPAP). $\mathrm{p}^{*}$ : $\mathrm{p}$ value for trend
Fig. 4 Central Illustration. The figure shows that there was good adaptation in subjects with a low baseline HR and that there was a reduced LV myocardial velocity in early diastole in subjects with a high baseline HR. $L V$ left ventricular, $R V$ right ventricular

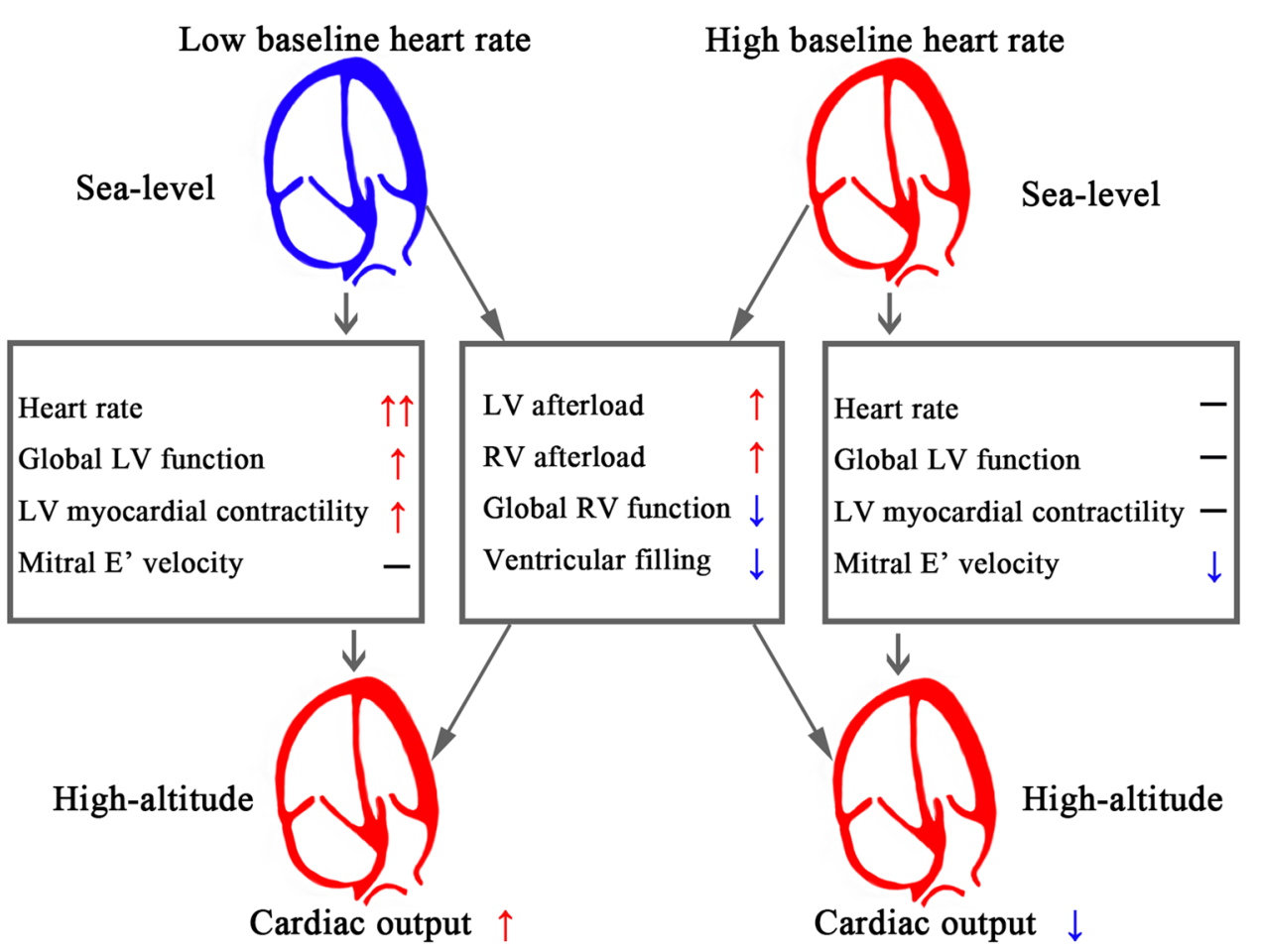


to the decrease in SV in these subjects [23]. Similarly, by reducing coronary perfusion and increasing myocardial $\mathrm{O}_{2}$ consumption during HA exposure, the elevated HR observed in patients with metabolic syndromes resulted in a deterioration of LV function via impaired LV filling and relaxation [24]. In contrast, pure HR reduction by ivabradine, a selective inhibitor of the pacemaker I(f) current, could prevent cardiac dysfunction and fibrosis [25]. Indeed, the autonomic nervous system response was upregulated under acute HA hypoxia, and the normal HR response characterized by HR acceleration from baseline acted as a compensatory mechanism to meet the body's increasing need for $\mathrm{O}_{2}$; however, an abnormal $\mathrm{HR}$ response in patients with nonobstructive coronary artery disease was usually associated with impaired cardiac function [26].

$\mathrm{HR}$, which is the most important determinant of myocardial oxygen consumption, plays a central role in the cardiac adaptation to sources of metabolic stress, such as hypoxia. The results from the Framingham heart study demonstrated that all-cause mortality increased by $14 \%$ for every increase of $10 \mathrm{bpm}$ in the baseline HR, and subjects with a baseline HR $>80 \mathrm{bpm}$ were significantly associated with a high risk of heart failure [27]. In addition, increasing evidence has documented that a low baseline HR usually represents a relatively good clinical outcome, and vice versa. Therefore, the baseline HR not only acted as a physiological predicator of the deterioration of cardiac function but also acted as a prognostic indicator of cardiovascular events [28]. In the present study, although the altered ventricular fillings, the elevated LV and RV afterload and the impairment of RV function might equally contribute to hypoxic adaptation in subjects with different baseline HRs, we also found that subjects with a low baseline HR adapted well to acute HA hypoxia by effectively utilizing heart rate reserve and enhancing LV myocardial contractility; in contrast, subjects with a high baseline HR showed a restricted $\mathrm{HR}$ response as well as reduced LV myocardial velocity in early diastole in response to acute HA exposure, which may be because a high baseline HR was associated with exaggerated energy expenditure, impaired myocardial oxygen delivery due to a short diastole period, and loss of the positive force-frequency relationship (Bowditch effect) [29]. Although these reasons could lead to a decrease in SV for subjects with a high baseline HR, the decreased SV and restricted HR could result in a reduced $\mathrm{CO}$, which was suggested to be a potential stimulus for cardiac functional remodeling if the HA exposure was prolonged [30].

\section{Study limitations}

The present observational study has some limitations. First, the enrolled participants were healthy young men, and whether the established results could be generalized to other types of individuals or circumstances (such as women, old adults, children, ascent to HA by other transport modes) is still unknown. Second, due to its complex anatomy, imaging the right ventricle with echocardiography is not an ideal approach. However, the evaluations of the right ventricle in our study were based on the guidelines published by the American Society of Echocardiography [31], and magnetic resonance imaging to assess the right ventricle is not feasible in a field study at HA. Finally, 2-dimensional echocardiography, like other imaging tools, has inherent limitations that impede a thorough evaluation of complex 3-dimensional anatomy. However, it is not ethical or practical to perform right heart catheterization in healthy individuals at HA for research purposes only. Nevertheless, echocardiography remains a simple and feasible method for field studies of HA. In the present study, the same well-trained operators who adopted strict reading criteria and were blinded to the subjects' grouping information performed all examinations. Therefore, such an approach could reduce the abovementioned limitations to a high degree.

\section{Conclusion}

For the first time, we demonstrated that the baseline HR of subjects at sea level could determine the cardiac responses to acute HA exposure, which were characterized by enhanced LV function in subjects with a low baseline HR and by reduced LV myocardial velocity in early diastole in subjects with a high baseline HR. Our findings provide novel insights into the cardiac responses to acute HA exposure, which could improve our understanding of the cardiac adaptations to acute HA hypoxia and guide our decision making for HA travels or work. Further investigations need to be performed to identify these effects in a larger population or in other types of subjects, such as patients with cardiovascular diseases.

Acknowledgements The authors thank Zhexue Qin, PhD, Shizhu Bian, $\mathrm{PhD}$, Xubin Gao, PhD, Jie Yu, PhD, Hu Tan, PhD, Jun Jin, PhD, Jingbin Ke, Fangzhengyuan Yuan, Chunyan He, Wenzhu Gu, Hedong Xiang, Ying Zeng, Chun Li, Jiabei Li, Dehui Qian, Rili Ge, PhD, who enthusiastically performed the literature search, manuscript improvements and data collection.

Author contributions All authors take responsibility for all aspects of the reliability and freedom from bias of the data presented and their discussed interpretation.

Funding This work was supported by grants from the National Natural Science Foundation of China (Grant No: 81730054), Military Logistics Research Project, PLA (Grant No: BLJ18J007) and the Special Health Research Project, Ministry of Health of PR China (No. 201002012). 


\section{Compliance with ethical standards}

Conflicts of interest The authors declare that they have no conflicts of interest.

Open Access This article is licensed under a Creative Commons Attribution 4.0 International License, which permits use, sharing, adaptation, distribution and reproduction in any medium or format, as long as you give appropriate credit to the original author(s) and the source, provide a link to the Creative Commons licence, and indicate if changes were made. The images or other third party material in this article are included in the article's Creative Commons licence, unless indicated otherwise in a credit line to the material. If material is not included in the article's Creative Commons licence and your intended use is not permitted by statutory regulation or exceeds the permitted use, you will need to obtain permission directly from the copyright holder. To view a copy of this licence, visit http://creativecommons.org/licenses/by/4.0/.

\section{References}

1. Bartsch P, Gibbs JS (2007) Effect of altitude on the heart and the lungs. Circulation 116(19):2191-2202. https://doi.org/10.1161/ CIRCULATIONAHA.106.650796

2. Osculati G, Revera M, Branzi G, Faini A, Malfatto G, Bilo G, Giuliano A, Gregorini F, Ciambellotti F, Lombardi C, Agostoni P, Mancia G, Parati G (2016) Effects of hypobaric hypoxia exposure at high altitude on left ventricular twist in healthy subjects: data from HIGHCARE study on Mount Everest. Eur Heart J Cardiovasc Imaging 17(6):635-643. https://doi.org/10.1093/ehjci/jev16 6

3. Stembridge M, Ainslie PN, Boulet LM, Anholm J, Subedi P, Tymko MM, Willie CK, Cooper SM, Shave R (2019) The independent effects of hypovolaemia and pulmonary vasoconstriction on ventricular function and exercise capacity during acclimatisation to $3800 \mathrm{~m}$. J Physiol 597(4):1059-1072. https://doi. org/10.1113/JP275278

4. Maufrais C, Rupp T, Bouzat P, Doucende G, Verges S, Nottin S, Walther G (2017) Heart mechanics at high altitude: 6 days on the top of Europe. Eur Heart J Cardiovasc Imaging 18(12):13691377. https://doi.org/10.1093/ehjci/jew286

5. Naeije R, Huez S, Lamotte M, Retailleau K, Neupane S, Abramowicz D, Faoro V (2010) Pulmonary artery pressure limits exercise capacity at high altitude. Eur Respir J 36(5):1049-1055. https:// doi.org/10.1183/09031936.00024410

6. Yang T, Li X, Qin J, Li S, Yu J, Zhang J, Yu S, Wu X, Huang L (2015) High altitude-induced borderline pulmonary hypertension impaired cardiorespiratory fitness in healthy young men. Int J Cardiol 181:382-388. https://doi.org/10.1016/j.ijcard.2014.12.044

7. Naeije R (2010) Physiological adaptation of the cardiovascular system to high altitude. Prog Cardiovasc Dis 52(6):456-466. https ://doi.org/10.1016/j.pcad.2010.03.004

8. Parati G, Agostoni P, Basnyat B, Bilo G, Brugger H, Coca A, Festi L, Giardini G, Lironcurti A, Luks AM, Maggiorini M, Modesti PA, Swenson ER, Williams B, Bartsch P, Torlasco C (2018) Clinical recommendations for high altitude exposure of individuals with pre-existing cardiovascular conditions: A joint statement by the European Society of Cardiology, the Council on Hypertension of the European Society of Cardiology, the European Society of Hypertension, the International Society of Mountain Medicine, the Italian Society of Hypertension and the Italian Society of Mountain Medicine. Eur Heart J 39(17):1546-1554. https://doi. org/10.1093/eurheartj/ehx720
9. Stembridge M, Ainslie PN, Shave R (2016) Mechanisms underlying reductions in stroke volume at rest and during exercise at high altitude. Eur J Sport Sci 16(5):577-584. https://doi. org/10.1080/17461391.2015.1071876

10. Opdahl A, Ambale Venkatesh B, Fernandes VRS, Wu CO, Nasir K, Choi EY, Almeida ALC, Rosen B, Carvalho B, Edvardsen T, Bluemke DA, Lima JAC (2014) Resting heart rate as predictor for left ventricular dysfunction and heart failure: MESA (MultiEthnic Study of Atherosclerosis). J Am Coll Cardiol 63(12):11821189. https://doi.org/10.1016/j.jacc.2013.11.027

11. Logeart D, Gueffet JP, Rouzet F, Pousset F, Chavelas C, Solal AC, Jondeau G (2009) Heart rate per se impacts cardiac function in patients with systolic heart failure and pacing: a pilot study. Eur J Heart Fail 11(1):53-57. https://doi.org/10.1093/eurjhf/hfn016

12. Vogel M, Schmidt MR, Kristiansen SB, Cheung M, White PA, Sorensen K, Redington AN (2002) Validation of myocardial acceleration during isovolumic contraction as a novel noninvasive index of right ventricular contractility: comparison with ventricular pressure-volume relations in an animal model. Circulation 105(14):1693-1699

13. Borlaug BA, Kane GC, Melenovsky V, Olson TP (2016) Abnormal right ventricular-pulmonary artery coupling with exercise in heart failure with preserved ejection fraction. Eur Heart J 37(43):3293-3302

14. Mitchell C, Rahko PS, Blauwet LA, Canaday B, Finstuen JA, Foster MC, Horton K, Ogunyankin KO, Palma RA, Velazquez EJ (2019) Guidelines for performing a comprehensive transthoracic echocardiographic examination in adults: recommendations from the American Society of Echocardiography. J Am Soc Echocar$\operatorname{diog} 32(1): 1-64$

15. Lang RM, Badano LP, Mor-Avi V, Afilalo J, Armstrong A, Ernande L, Flachskampf FA, Foster E, Goldstein SA, Kuznetsova T, Lancellotti P, Muraru D, Picard MH, Rietzschel ER, Rudski L, Spencer KT, Tsang W, Voigt JU (2015) Recommendations for cardiac chamber quantification by echocardiography in adults: an update from the American Society of Echocardiography and the European Association of Cardiovascular Imaging. Eur Heart J Cardiovasc Imaging 16(3):233-270. https://doi.org/10.1093/ehjci /jev014

16. Andersen OS, Smiseth OA, Dokainish H, Abudiab MM, Schutt RC, Kumar A, Sato K, Harb S, Gude E, Remme EW, Andreassen AK, Ha JW, Xu J, Klein AL, Nagueh SF (2017) Estimating left ventricular filling pressure by echocardiography. J Am Coll Cardiol 69(15):1937-1948. https://doi.org/10.1016/j. jacc.2017.01.058

17. Trinity JD, Pahnke MD, Lee JF (1985) Coyle EF (2010) Interaction of hyperthermia and heart rate on stroke volume during prolonged exercise. J Appl Physiol 109(3):745-751. https://doi. org/10.1152/japplphysiol.00377.2010

18. Allemann Y, Rotter M, Hutter D, Lipp E, Sartori C, Scherrer U, Seiler C (2004) Impact of acute hypoxic pulmonary hypertension on LV diastolic function in healthy mountaineers at high altitude. Am J Physiol Heart Circ Physiol 286(3):H856-862. https://doi. org/10.1152/ajpheart.00518.2003

19. Holloway CJ, Montgomery HE, Murray AJ, Cochlin LE, Codreanu I, Hopwood N, Johnson AW, Rider OJ, Levett DZ, Tyler DJ, Francis JM, Neubauer S, Grocott MP, Clarke K (2011) Cardiac response to hypobaric hypoxia: persistent changes in cardiac mass, function, and energy metabolism after a trek to Mt. Everest Base Camp. FASEB J 25(2):792-796. https://doi.org/10.1096/ fj.10-172999

20. Chung CS, Afonso L (2016) Heart rate is an important consideration for cardiac imaging of diastolic function. JACC Cardiovasc Imaging 9(6):756-758. https://doi.org/10.1016/j. jemg.2015.10.021 
21. Mourot L (2018) Limitation of maximal heart rate in hypoxia: mechanisms and clinical importance. Front Physiol 9:972. https ://doi.org/10.3389/fphys.2018.00972

22. Peverill RE, Chou B, Donelan L (2017) Left ventricular long axis tissue Doppler systolic velocity is independently related to heart rate and body size. PLoS ONE 12(3):e0173383. https://doi. org/10.1371/journal.pone.0173383

23. Nagueh SF, Smiseth OA, Appleton CP, Byrd BF 3rd, Dokainish H, Edvardsen T, Flachskampf FA, Gillebert TC, Klein AL, Lancellotti P, Marino P, Oh JK, Popescu BA, Waggoner AD (2016) Recommendations for the evaluation of left ventricular diastolic function by echocardiography: an update from the American Society of Echocardiography and the European Association of Cardiovascular Imaging. J Am Soc Echocardiogr 29(4):277-314. https://doi.org/10.1016/j.echo.2016.01.011

24. Merabet N, Fang Y, Nicol L, Monteil C, Remy-Jouet I, Henry JP, Wecker D, Le Bouter-Banon S, Roussel J, Richard V, Thuillez C, Mulder P (2015) Selective heart rate reduction improves metabolic syndrome-related left ventricular diastolic dysfunction. J Cardiovasc Pharmacol 66(4):399-408. https://doi.org/10.1097/ FJC.0000000000000294

25. Busseuil D, Shi Y, Mecteau M, Brand G, Gillis MA, Thorin E, Asselin C, Romeo P, Leung TK, Latour JG, Des Rosiers C, Bouly M, Rheaume E, Tardif JC (2010) Heart rate reduction by ivabradine reduces diastolic dysfunction and cardiac fibrosis. Cardiology 117(3):234-242. https://doi.org/10.1159/000322905

26. Chaudhry S, Kumar N, Behbahani H, Bagai A, Singh BK, Menasco N, Lewis GD, Sperling L, Myers J (2017) Abnormal heart-rate response during cardiopulmonary exercise testing identifies cardiac dysfunction in symptomatic patients with nonobstructive coronary artery disease. Int J Cardiol 228:114-121. https://doi.org/10.1016/j.ijcard.2016.11.235
27. Kannel WB, Kannel C, Paffenbarger RS Jr, Cupples LA (1987) Heart rate and cardiovascular mortality: the Framingham Study. Am Heart J 113(6):1489-1494

28. Oliva F, Sormani P, Contri R, Campana C, Carubelli V, Ciro A, Morandi F, Di Tano G, Mortara A, Senni M, Metra M, Ammirati E (2018) Heart rate as a prognostic marker and therapeutic target in acute and chronic heart failure. Int J Cardiol 253:97-104. https ://doi.org/10.1016/j.ijcard.2017.09.191

29. Bohm M, Perez AC, Jhund PS, Reil JC, Komajda M, Zile MR, McKelvie RS, Anand IS, Massie BM, Carson PE, McMurray JJ (2014) Relationship between heart rate and mortality and morbidity in the irbesartan patients with heart failure and preserved systolic function trial (I-Preserve). Eur J Heart Fail 16(7):778-787. https://doi.org/10.1002/ejhf.85

30. Stembridge M, Ainslie PN, Shave R (2015) Short-term adaptation and chronic cardiac remodelling to high altitude in lowlander natives and Himalayan Sherpa. Exp Physiol 100(11):1242-1246. https://doi.org/10.1113/expphysiol.2014.082503

31. Rudski LG, Lai WW, Afilalo J, Hua L, Handschumacher MD, Chandrasekaran K, Solomon SD, Louie EK, Schiller NB (2010) Guidelines for the echocardiographic assessment of the right heart in adults: a report from the American Society of Echocardiography endorsed by the European Association of Echocardiography, a registered branch of the European Society of Cardiology, and the Canadian Society of Echocardiography. J Am Soc Echocardiogr 23(7):685-713. https://doi.org/10.1016/j.echo.2010.05.010

Publisher's Note Springer Nature remains neutral with regard to jurisdictional claims in published maps and institutional affiliations. 